\title{
Implementasi Patient Safety di Pelayanan Anak Rumah Sakit Umum Haji Medan Tahun 2019
}

\author{
Verawaty Sari Simamora*, Zulfendri ${ }^{* *}$, Roymond H Simamora ${ }^{* *}$, Puteri Citra Cinta Asyura Nasution ${ }^{* *}$ \\ ${ }^{*}$ Fakultas Kesehatan Masyarakat, Universitas Sumatera Utara \\ ** Fakultas Kesehatan Masyarakat, Universitas Sumatera Utara \\ Email:verawatysarisimamora@gmail.com
}

\section{ABSTRACT}

The complexity of diversity, relationships, variety and specialization can provide more opportunities for mistakes, one of which is in the children's hospital services. Based on patient safety incident report data at Rumah Sakit Umum Haji Medan in January 2018 to October 2018, it is known that child care is the unit with the highest number of patient safety incidents compared to other units at 37 incidents. Implementation of patient safety by officers in children's services is the main focus that must be considered its role to prevent the occurrence of patient safety incidents. This research is a qualitative research that aims to see the extent of the implementation of patient safety in child care at Rumah Sakit Umum Haji Medan from the description of the role of health workers involved in child care, namely the role of the head of a child's SMF, the role of a pediatrician, and the role of a child nurse. Data collection was carried out by in-depth interviews with 7 informants and through observation. The results showed the implementation of patient safety in children's services has not been running optimally. This is because not all health workers in child services, namely the head of the child's SMF, pediatricians and child nurses do their part in the patient safety system. The roles carried out are still focused on the standards of each profession. It is expected that routine socialization on the implementation of patient safety, the implementation of special meetings and discussions to study the patient safety system and the existence of patient safety drivers in child care designated as the person responsible for moving every officer to implement patient safety.

Keywords : Implementation, Children's Services, Patient Safety

\section{PENDAHULUAN}

Keselamatan pasien adalah elemen penting dari sistem pelayanan kesehatan yang efektif dan efisien untuk meningkatkan kualitas pelayanan. Rumah sakit merupakan salah satu pelayanan kesehatan yang wajib menerapkan keselamatan pasien karena bersifat kompleks, sehingga memberikan lebih banyak kesempatan untuk terjadinya kesalahan. Kesalahan di rumah sakit dapat terjadi ketika tidak memberikan pelayanan yang seharusnya dilakukan, ataupun memberikan pelayanan yang seharusnya tidak dilakukan. Luasnya ruang lingkup pelayanan rumah sakit menjadi penyebab insiden keselamatan pasien rentan terjadi, sehingga dapat menimbulkan kerugian yang besar. Pelayanan anak rumah sakit merupakan salah satu unit yang memiliki kejadian insiden keselamatan pasien terbesar dikarenakan anak rentan terhadap bahaya yang terkait dengan perawatan medis. Anakanak memerlukan perhatian khusus terhadap keselamatan dirinya karena masih berada pada tahap pertumbuhan dan perkembangan. ${ }^{1}$ 
Selain itu, tenaga kesehatan yang memiliki keterampilan khusus dalam melakukan perawatan pasien anak terbatas jumlahnya karena mereka lebih banyak dipersiapkan untuk merawat pasien dewasa (American Academy of Pediatric, 2011).

Menurut studi yang dilakukan di Kanada mengenai adverse event tahun 2008-2009, terjadi rata-rata KTD di rumah sakit sebanyak 9,2\% dari 3669 anak. KTD terjadi pada bayi sebanyak $75 \%$ dikarenakan prosedur medis, pasien anak usia $>1$ tahun sebanyak $75 \%$ dikarenakan pemberian obat, pasien anak usia $>5$ tahun sebanyak $64 \%$ karena pembedahan, $47 \%$ karena pemeriksaan diagnostik, dan $43 \%$ karena pemberian obat. ${ }^{2}$ Di Indonesia, tercatat jumlah insiden keselamatan pasien berdasarkan spesialisasi paling banyak disebabkan oleh unit anak sebesar $6,17 \%$ pada periode Januari-April 2010 dan sebesar 8\% pada periode Mei sampai Agustus 2010 (KKPRS, 2010).

Berdasarkan survei pendahuluan yang dilakukan di Rumah Sakit Umum Haji Medan,diketahui jumlah insiden keselamatan pasien paling banyak terdapat di pelayanan anak dibandingkan dengan unit lain yaitu sebanyak 37 insiden yang terdiri atas 16 KTD, 7 KNC, 7 KPC dan 7 KTC. Kasus KTD yang didapatkan berupa infeksi phlebitis yang terjadi pada 7 pasien anak. Data insiden keselamatan pasien hanya sebatas data, semua kasus yang tercatat hanya kasus yang diketahui secara kebetulan, masih ada kasuskasus yang tidak dilaporkan karena petugas kurang memahami pelaporan insiden keselamatan pasien dan tidak menyadari jika suatu kesalahan telah terjadi karena kurangnya kemampuan mengidentifikasi insiden keselamatan pasien. Petugas di pelayanan anak sudah memahami pelaksanaan keselamatan pasien sesuai dengan standar dan sasaran keselamatan pasien, namun peran petugas kesehatan masih belum terlihat dalam pelaksanaan keselamatan pasien di pelayanan anak.

Insiden keselamatan pasien masih tetap ada, padahal seharusnya insiden keselamatan pasien berada pada nilai zero defect (tingkat insidensi 0\%). Oleh karena itu, penelitian ini bertujuan untuk mendeskripsikan implementasi patient safety di pelayanan anak RSU Haji Medan tahun 2019 yaitu mendeskripsikan peran kepala Satuan Medis Fungsional (SMF) anak, peran dokter anak, dan perawat anak dalam implementasi patient safety di pelayanan anak RSU Haji Medan.

\section{METODE PENELITIAN}

Penelitian ini merupakan penelitian kualitatif dengan pendekatan fenomonologi. Penelitian dilakukan di pelayanan anak Rumah Sakit Umum Haji Medan pada bulan Juni sampai Juli 2019 dengan wawancara mendalam dan observasi. Informan dalam penelitian ini adalah Kepala SMF anak, dokter anak, perawat anak, kepala ruangan pelayanan anak, ketua peningkatan mutu dan keselamatan pasien.

\section{HASIL DAN PEMBAHASAN}

Tujuh langkah pelaksanaan keselamatan pasien, yaitu :

\section{Membangun Kesadaran Akan Nilai Keselamatan Pasien.}

Peran Kepala SMF Anak di pelayanan anak Rumah Sakit Umum Haji Medan dalam membangun kesadaran akan nilai keselamatan pasien dilakukan dengan memberitahu dokter untuk melakukan pelayanan dengan bertanggung jawab dan melakukan follow-up dengan bertanya kepada dokter apabila terjadi suatu masalah dalam pelayanan klinis yang dilakukan. Menurut dokter anak, kepala SMF anak dalam membangun kesadaran akan nilai keselamatan pasien lebih kepada prinsip dalam melakukan pelayanan klinis, mengenai keselamatan pasien belum dibahas secara khusus dan belum pernah disosialisasikan. Begitu juga dengan pernyataan ketua PMKP yang mengatakan bahwa dalam membangun kesadaran akan nilai keselamatan pasien di pelayanan anak sudah dilakukan, namun tidak terlalu mendetail disosialisasikan kepada kepala SMF anak.

Menurut Permenkes No 11 Tahun 2017 dalam membangun kesadaran diperlukan lingkungan dengan budaya yang adil dan terbuka dalam melaksanakan keselamatan pasien.3 Peran pemimpin sangat penting 
dalam mengatur anggota-anggotanya untuk membangun kesadaran dan mendukung stafnya dalam melaksanakan keselamatan pasien seperti memberikan sosialisasi dan menjadikan keselamatan pasien sebagai agenda prioritas saat melakukan rapat atau pertemuan. Kepala SMF anak RSU Haji Medan masih berpatokan dalam lingkup klinis saja, terlihat dari pernyataannya yang terfokus kepada pelayanan medis. Sosialisasi khusus tentang patient safety belum dilakukan, pembahasan yang sering dibicarakan masih seputar kondisi atau masalah yang terjadi pada pasien, sehingga tentang system keselamatan pasien secara utuh belum terealisasi dengan baik.

Peran Dokter Anak di Pelayanan Anak Rumah Sakit Umum Haji Medan mengenai membangun kesadaran akan nilai keselamatan pasien kepada dokter, yaitu dengan memegang prinsip memberikan pelayanan yang aman kepada pasien, namun poin-poin khusus terkait keselamatan pasien belum diketahui secara utuh oleh dokter karena fokus dokter masih kepada pemberian pelayanan medis. Menurut ketua PMKP, dalam membangun kesadaran akan nilai keselamatan pasien kepada dokter yang penting menyadari pemberian tindakan yang aman ke pasien. Dalam membangun kesadaran akan nilai keselamatan pasien diperlukan budaya yang adil dan terbuka, dimana staf berani melapor dan melakukan tindakan penanganan insiden dengan sistematik (Permenkes 11, 2017). ${ }^{3}$ Dokter di pelayanan anak RSU Haji Medan sudah memahami pentingnya nilai keselamatan pasien mengenai melakukan pelayanan medis dengan tindakan yang aman, kesadaran untuk memprioritaskan keselamatan pasien lewat pelayanannya masing-masing sudah tertanam, namun terkait dengan sistem keselamatan pasien yang berani melakukan pelaporan insiden dan pembelajaran serta pelaksanaan tindakan solusi yang tepat belum berjalan sepenuhnya, dokter lebih terfokus kepada melakukan pelayanan medis.

Peran perawat pelayanan anak terkait membangun kesadaran akan nilai keselamatan pasien diketahui bahwa perawat melakukan diskusi dan sharing dengan sesama rekan sekerja mengenai pentingnya mengutamakan keselamatan pasien. Menurut pernyataan kepala ruang dalam membangun kesadaran akan nilai keselamatan pasien dilakukan dengan adanya sosialisasi yang diberikan tentang prinsip dalam melakukan pelayanan kepada pasien harus benar dan aman. Hasil observasi menunjukkan bahwa perawat sudah pada tahap ikut sosialisasi atau pelatihan dan sudah tersedianya jadwal petugas turun ke ruangan untuk meminimalisir insiden keselamatan pasien. Berdasarkan Permenkes No 11 Tahun 2017, dalam membangun kesadaran akan nilai keselamatan pasien diperlukan lingkungan dengan budaya yang adil dan terbuka, dimana staf berani melapor dan melakukan tindakan penanganan insiden dengan sistematik. ${ }^{3}$

Perawat anak di pelayanan anak RSU Haji Medan sudah sama-sama membangun kesadaran akan nilai keselamatan pasien melalui diskusi dan pemberian sosialisasi khusus tentang keselamatan pasien, namun dalam menerapkan budaya adil dan terbuka yaitu kesadaran untuk berani melakukan pelaporan belum maksimal. Perawat menyadari pelaksanaanya masih belum menjadi kebiasaan, harus digerakkan terlebih dahulu. Hasil observasi yang didapat juga belum menunjukkan adanya reward dan punishment yang diberikan untuk meningkatkan kesadaran akan nilai keselamatan pasien di pelayanan anak.

\section{Memimpin Dan Mendukung Staf.}

Hasil wawancara terkait memimpin dan mendukung staf yang dilakukan oleh kepala SMF anak yaitu mengatur setiap dokter anak dan memberikan kepercayaan kepada mereka dalam mengerjakan tanggung jawabnya masing-masing. Kepala SMF anak tidak melakukan supervisi karena dokter sudah memiliki tugas untuk mengevaluasi pelayanan yang dilakukannya sendiri. Menurut pernyataan dari dokter anak, kepala SMF anak dalam memimpin dan mendukung staf dirasakan kompak dengan setiap anggotanya dan membangun setiap dokter untuk samasama memegang komitmen dalam 
melakukan tindakan yang aman kepada pasien.

Menurut ketua PMKP (Peningkatan Mutu Keselamatan Pasien), kepala SMF anak dalam memimpin dan mendukung staf dilakukan dengan saling mengingatkan satu sama lain. Kepala SMF anak tidak monoton dan memiliki hubungan yang baik dan kompak dengan para dokter anak dalam memimpin dan mendukung staf, namun kepemimpinan yang dilakukan masih tentang pemberian pelayanan klinis yang aman, belum mengetahui seputar system keselamatan pasien secara utuh.

Hasil observasi yang dilakukan menunjukkan kepala SMF anak belum melakukan pelatihan mengenai keselamatan pasien, terlihat dari alat bukti sertifikasi pelatihan yang belum ada. Kepala SMF anak belum menjadi penggerak keselamatan pasien di pelayanan anak rumah sakit seperti memberikan sosialisasi atau rapat pertemuan dengan memasukkan topik keselamatan pasien secara khusus karena pemahaman keselamatan pasien yang diketahui hanya sebatas pelayanan medis yang mengutamakan keselamatan pasien dan memberikan tindakan pelayanan yang aman.

Menurut Permenkes No 11 Tahun 2017, seharusnya dalam memimpin dan mendukung staf dilakukan dengan membuat agenda pertemuan di unit dan memasukkan keselamatan pasien ke dalam program pelatihan.3 Adanya program pelatihan yang dibuat, artinya sebagai pemimpin yang membuat pelatihan harusnya mendapatkan pelatihan keselamatan pasien terlebih dahulu. Dalam organisasi perubahan tidak akan terjadi tanpa kepemimpinan yang kuat serta dukungan sumber daya manusia yang andal (Cahyono, 2008). ${ }^{4}$ Oleh karena itu, dalam pelaksanaannya perlu adanya pemimpin yang betul-betul mengerti tentang keselamatan pasien.

\section{Mengintegrasikan Aktivitas Pengelolaan Risiko.}

Hasil wawancara yang dilakukan dengan kepala SMF anak dalam mengintegrasikan aktivitas pengelolaan risiko lebih memfokuskan kepada pembuatan diagnostik pasien dan pengobatan secara rasional. Pembahasan mengenai risiko-risiko pasien seperti melakukan diskusi tentang apa saja risiko yang bisa terjadi di unit anak belum dilakukan. Kepala SMF anak RSU Haji Medan belum melakukan pengelolaan risiko seperti yang tertulis di Permenkes No 11 Tahun 2017 dengan mendiskusikan isu-isu keselamatan pasien guna memberikan umpan balik kepada manajemen yang terkait yang membahas penilaian risiko pada individu pasien dalam proses asesmen risiko untuk menentukan akseptabilitas setiap risiko dan pengambilan langkah-langkah yang tepat untuk memperkecil risiko tersebut. ${ }^{3}$

Hasil wawancara yang dilakukan dengan dokter anak terkait mengintegrasikan aktivitas pengelolaan risiko kepada dokter yaitu dengan memperhatikan hal-hal apa yang bisa membahayakan kondisi pasien, sehingga pasien harus diperhatikan secara khusus melalui simbol-simbol yang ada menjadi suatu pencegahan untuk meminimalisir terjadinya risiko terhadap pasien. Mengenai manajemen risiko klinis dan non klinis dokter belum mengetahui. Menurut ketua PMKP, integrasi aktivitas pengelolaan risiko dilakukan dengan membahas dan mendiskusikan masalah atau risiko apa yang terjadi sampai kepada indikator area klinis dan non klinis, namun pengerjaannya belum optimal, hal tersebut masih pada tahap teoritis saja. Dokter di pelayanan anak RSU Haji Medan sudah memahami tentang risiko-risiko yang bisa terjadi pada pasien dan penilaian risiko pada pasien yang dilakukan melalui simbol-simbol yang terkait dengan keselamatan pasien, namun mengenai penerapan manajemen risiko klinis dan non klinis secara utuh belum terealisasi, padahal penilaian risiko melalui simbol-simbol keselamatan pasien yang dibahas oleh dokter merupakan salah satu manajemen risiko klinis.

Berdasarkan Permenkes No 11 Tahun 2017, perlu adanya pengembangan sistem dan proses pengelolaan risiko, serta melakukan identifikasi dan asesmen hal yang potensial bermasalah untuk meminimalisir terjadinya 
risiko dan sebagai pembelajaran dalam melakukan pengelolaan risiko. ${ }^{3}$

Peran perawat anak dalam mengintegrasikan aktivitas pengelolaan risiko, perawat sudah melakukan pengelolaan risiko dengan memperhatikan penilaian risiko dan melalui simbol-simbol yang berhubungan dengan keselamatan pasien untuk mencegah terjadinya risiko, seperti pemberian tanda warna kuning di tempat tidur pasien sebagai simbol yang menandakan pasien berisiko jatuh. Hasil observasi juga menunjukkan bahwa perawat sudah melakukan pengelolaan risiko dengan adanya bukti alur pengelolaan risiko pasien jatuh. Namun, perawat masih lebih fokus kepada penilaian dan pengelolaan risiko jatuh saja, padahal banyak risiko-risiko yang bisa diperhatikan ketika pasien berada di rumah sakit untuk dilakukan asesmen risiko seperti yang tertulis di Permenkes No 11 Tahun 2017.

\section{Melakukan Pelaporan Insiden.}

Hasil wawancara yang dilakukan kepada kepala SMF anak mengenai melakukan pelaporan insiden diperoleh informasi, bahwa kepala SMF anak tidak mengetahui perihal pelaporan insiden karena itu lebih kepada tugas perawat.

Hasil penelitian ini sama dengan Tristantia (2018), pembuatan laporan insiden masih dilimpahkan kepada satu petugas, belum sesuai dengan kebijakan yang berlaku dimana petugas yang menemukan insiden wajib terlibat dalam pembuatan laporan insiden. ${ }^{5}$ Dalam sistem pelaporan insiden, diatur bahwa setiap petugas kesehatan yang menemukan atau melakukan insiden harus menuliskan laporan sebagai sarana untuk belajar. ${ }^{6}$ Kepala SMF anak seharusnya mengetahui bagaimana system pelaporan insiden untuk meningkatkan pelaksanaan keselamatan pasien.

Hasil wawancara yang dilakukan kepada dokter anak terkait melakukan pelaporan insiden yaitu dokter mengetahui adanya pelaporan insiden, namun pelaporan bukan menjadi urusan dokter melainkan perawat. Hal tersebut juga sama seperti yang dikatakan oleh ketua PMKP bahwa mengenai pelaporan insiden tidak pernah dilakukan oleh dokter, dokter mendapatkan laporan dari perawat.

Hal ini tidak sejalan dengan Firawati (2012) yang mengatakan bahwa setiap pihak yang terlibat dalam aktivitas pelayanan kesehatan merupakan orang yang berisiko untuk insiden keselamatan pasien, sehingga setiap petugas kesehatan melakukan sistem pelaporan insiden yang berpotensi menimbulkan risiko dalam budaya tidak saling menyalahkan sebagai metode untuk mengenali risiko. ${ }^{7}$ Dokter di pelayanan anak RSU Haji Medan mengetahui adanya pelaporan insiden, namun tidak memahami bagaimana pelaporan itu dilakukan, sehingga menurut dokter tugas dalam melakukan pelaporan itu merupakan urusan perawat. Proses pelaporan insiden menjadi tanggung jawab setiap orang dalam sistem pelayanan kesehatan. Dokter sebagai pemberi pelayanan klinis seharusnya juga melakukan pelaporan ketika terjadi insiden disaat melakukan pelayanan, bukan hanya perawat saja yang melakukan pelaporan insiden.

Peran perawat anak terkait melakukan pelaporan insiden bahwa perawat sudah melakukan pelaporan insiden di pelayanan anak dengan mencatat kejadian yang terjadi kemudian dituliskan di buku pelaporan khusus yaitu "incident report". Hasil observasi juga menunjukkan sudah terdapat incident report di unit anak. Perawat anak di RSU Haji Medan memahami pentingnya pelaporan insiden dan sudah melakukannya, namun dalam pelaksanaannya ditemukan beberapa kendala dari pernyataan perawat dan kepala ruangan yaitu kurangnya kesadaran, motivasi dan keterbatasan SDM dibagian perawat akibatnya sulit untuk melakukan pelaporan insiden.

Berdasarkan Permenkes No 11 Tahun 2017 sistem pelaporan sangat vital di dalam pengumpulan informasi yang digunakan sebagai dasar analisa dan menyampaikan rekomendasi, sehingga pelaporan insiden harus benar-benar dilaksanakan. ${ }^{3}$

\section{Melakukan Komunikasi.}

Hasil wawancara yang dilakukan terhadap kepala SMF anak dalam melakukan 
komunikasi diperoleh informasi mengenai komunikasi kerjasama tim dan komunikasi pada pasien.

Berdasarkan pernyataan kepala SMF anak mengenai komunikasi kerjasama tim kepada dokter dan perawat diketahui bahwa komunikasi yang dilakukan terhadap dokter lebih kepada seputar pelayanan medis yang dilakukan ke pasien, jika ditemukan masalah, kepala SMF anak ikut terlibat dalam penyelesaiannya. Komunikasi kepada perawat seputar pelaporan yang dilakukan perawat tentang kondisi pasien. Kepala SMF anak lebih menjelaskan tentang cara melakukan komunikasi perawat ke dokter dalam menangani kasus atau kondisi pasien. Kepala SMF anak RSU Haji Medan sudah melakukan komunikasi yang baik kepada dokter, dimana sebagai pemimpin sudah memberikan panduan melakukan pelayanan kepada pasien dan pembahasan seputar pelayanan medis selalu ditekankan.

Hasil wawancara terkait komunikasi pada pasien menurut kepala SMF anak dilakukan saat melakukan diagnosis pasien supaya mengetahui penyakit yang dialami oleh pasien. Berdasarkan Permenkes No 11 Tahun 2017, pasien dan keluarganya harus mendapatkan informasi yang benar dan jelas karena pasien juga merupakan peranan kunci dalam membantu penegakan diagnosa yang akurat. Kepala SMF anak RSU Haji Medan sudah mengarahkan setiap dokter dalam memberikan pelayanan ke pasien harus melakukan komunikasi terbuka yaitu dalam hal menentukan diagnosa penyakit, namun mengenai insiden yang terjadi kepada pasien belum ada dibicarakan utuh bagaimana mengomunikasikannya secara jelas dan tepat kepada pasien.

Hasil wawancara yang dilakukan terkait komunikasi yang dilakukan dokter diperoleh informasi mengenai komunikasi dalam kerja tim dan komunikasi pada pasien. Komunikasi kerja tim yang dilakukan dokter dalam melakukan pelayanan berjalan baik dan mengutamakan keselamatan pasien, namun dalam pelaksanaannya masih ada misscommunication yang pernah terjadi antara dokter dan perawat yaitu komunikasi melalui telepon, karena faktor tengah malam yang menyebabkan perawat kurang fokus mendengar, padahal perawat sudah mengetahui adanya metode khusus ketika berkomunikasi lewat telepon untuk menghindari kejadian yang tidak diinginkan. Hasil observasi yang didapat juga menunjukkan sudah terdapat kebijakan tentang melakukan komunikasi efektif dengan metode SBAR, namun metode tersebut hanya dilakukan ketika mengalami keraguan saja, padahal seharusnya saat melakukan komunikasi untuk menghindari misscommunication terjadi. Pelaksanaan komunikasi antara perawat dan dokter di pelayanan anak RSU Haji Medan sudah dilakukan dengan metode komunikasi efektif, tetapi belum diterapkan seutuhnya, penerapannya hanya dilakukan ketika mengalami sangsi saja. Hasil wawancara mengenai komunikasi yang dilakukan dokter terhadap pasien lebih kepada diagnosa yang dilakukan dengan terbuka dan jelas, dan melibatkan pasien dalam pengambilan keputusan klinis.

Sejalan dengan Cahyono (2008) mengenai menjalin komunikasi antara dokter dengan pasien dilakukan dengan mengoptimalkan proses penemuan diagnosis penyakit dan terapi, menjembatani kesenjangan antara pengetahuan dokter dan pasien dalam rangka pengambilan keputusan medis bersama, membangun kepercayaan, mencegah dan mengurangi risiko tuntutan medikolegal. ${ }^{4}$

Peran perawat anak dalam melakukan komunikasi diperoleh informasi tentang komunikasi kepada pasien, yaitu perawat sudah melakukan komunikasi terbuka kepada pasien saat asuhan pelayanan dan pada saat terjadi risiko ataupun sebelum terjadi risiko karena perlakuan medis. Berdasarkan hasil observasi yang dilakukan, belum adanya kebijakan khusus tentang komunikasi terbuka dengan pasien dan keluarga terkait insiden yang terjadi pada pasien. Memastikan para pasien dan keluarga mendapat informasi yang benar dan jelas, memberikan dukungan, pelatihan serta dorongan semangat kepada staf agar selalu terbuka kepada pasien dan keluarganya merupakan komunikasi terbuka 
kepada pasien yang harus dilakukan untuk meningkatkan keselamatan pasien (Permenkes, 2017). Perawat anak di RSU Haji Medan sudah melakukan komunikasi pasien dengan baik, namun mengenai kebijakan khusus tentang melakukan komunikasi terbuka terkait insiden keselamatan pasien yang terjadi belum ada, sehingga pelaksanaan keselamatan pasien lewat pemberian komunikasi terbuka belum berjalan sepenuhnya.

\section{Mempelajari Tentang Keselamatan Pasien.}

Hasil wawancara dengan kepala SMF anak diketahui bahwa dalam mempelajari keselamatan pasien dilakukan secara mandiri, intinya mengerjakan pelayanan sesuai dengan tanggung jawab yang diberikan dengan belajar empati dan profesional.

Pembelajaran tentang keselamatan pasien seharusnya dilakukan dengan saling berbagi pengalaman dengan sesama rekan sekerja, melakukan diskusi untuk berbagi pengalaman tentang keselamatan pasien seperti bagaimana hasil analisis insiden yang dilakukan. ${ }^{2}$ Sebagai pemimpin, kepala SMF anak harusnya bisa mengembangkan pembelajaran keselamatan pasien bersamasama dengan tepat, yaitu dengan mengidentifikasi penyebab insiden yang terjadi yang terkait dengan keselamatan pasien.

Hasil wawancara yang dilakukan pada dokter anak terkait mempelajari keselamatan pasien yaitu dokter masing-masing melakukan pembelajaran mandiri dan belajar melalui risiko-risiko apa yang bisa terjadi pada pasien. Berbeda dengan yang dikatakan oleh ketua PMKP, dimana dokter dalam mempelajari keselamatan pasien harusnya saling mengingatkan satu sama lain, artinya pembelajaran keselamatan pasien dilakukan bersama-sama. Dokter anak di RSU Haji Medan mengetahui keselamatan pasien pada dasarnya adalah melakukan pelayanan aman kepada pasien. Dokter juga sudah mau melakukan pembelajaran tentang keselamatan pasien, namun tahapan pembelajaran yang dilakukan masih sendiri-sendiri, belum ada melakukan pertemuan khusus untuk membahas tentang sistem keselamatan pasien. Padahal seharusnya dalam mempelajari keselamatan pasien perlu adanya diskusi mengenai isu keselamatan pasien, mempelajari bagaimana suatu kejadian bisa terjadi dan akhirnya menjadi pembelajaran kedepan dalam melakukan pelayanan. ${ }^{3}$

Peran perawat anak dalam mempelajari keselamatan pasien dilakukan dengan bersama-sama dan saling membicarakan topic tentang keselamatan pasien. Berdasarkan hasil observasi yang dilihat, belum adanya blanko metode pemecahan masalah dan kebijakan dan laporan analisis akar masalah serta bukti melakukan diskusi dengan unit lain belum tersedia.

Berdasarkan Permenkes No 11 Tahun 2017, mempelajari keselamatan pasien merupakan belajar dan berbagi pengalaman tentang keselamatan pasien dimana setiap anggota yang terkait terlatih untuk melakukan kajian insiden secara tepat untuk mengidentifikasi penyebab dan mengembangkan kebijakan kriteria pelaksanaan analisis akar masalah yang mencakup insiden yang terjadi.3 Perawat anak di RSU Haji Medan sudah melakukan pembelajaran keselamatan pasien dengan berbagai pengalaman antar anggota yang satu dan yang lain, namun mengenai kajian insiden dan pelaksanaan analisis akar masalah belum terealisasi.

\section{Mencegah Cedera Melalui Implementasi Sistem Keselamatan Pasien.}

Hasil wawancara dengan kepala SMF anak terkait pencegahan cedera dilakukan dengan membuat suatu diagnosis dan memperhatikan perawatan yang diberikan ke pasien sudah benar atau tidak. Berdasarkan Permenkes No 11 Tahun 2017, pencegahan cedera melalui implementasi sistem keselamatan pasien dilakukan dengan melibatkan tim di unit atau pelayanan dalam pengembangan cara-cara agar asuhan pasien lebih baik dan aman. Selain itu, perlu adanya pembelajaran lewat perubahan di dalam praktek, proses atau sistem dengan melakukan pengkajian ulang terhadap perubahanperubahan yang sudah dibuat dalam 
mengimplementasikan system keselamatan pasien. Kepala SMF anak sudahmelakukan pengembangan cara-cara agar asuhan terhadap pasien lebih baik dan aman, namun pembelajaran lewat perubahan- perubahan yang sudah dibuat dalam mengimplementasikan sistem keselamatan pasien belum terealisasi karena kepala SMF hanya membahas mengenai pemberian pelayanan klinis yang dilakukan untuk menghindari terjadinya cedera saat melayani pasien.

Hasil wawancara yang dilakukan pada dokter anak mengenai mencegah cedera melalui implementasi sistem keselamatan pasien kepada dokter yaitu dokter memberikan pelayanan sesuai dengan SOP dan penanganan yang aman. Menurut ketua PMKP, dokter melakukan pencegahan cedera dengan mengikuti pelatihan yang terkait pelayanan medis. Mengenai pembahasan tentang kejadian yang terjadi pada pasien sebagai pembelajaran dalam mengimplementasikan solusi-solusi terkait keselamatan pasien untuk mencegah terjadinya cedera pada pasien belum terlihat.

Hal tersebut sejalan dengan penelitian Islami (2018) yang mengatakan bahwa dalam mencegah cedera melalui implementasi sistem keselamatan sudah dilakukan dengan pengembangan asuhan pasien yang lebih baik dan aman, namun belum terdapat pertemuan atau agenda khusus yang membahas keselamatan pasien. ${ }^{8}$ Dokter di pelayanan anak RSU Haji Medan sudah memberikan pelayanan dengan asuhan yang lebih baik dan aman sesuai dengan SOP, namun pembelajaran terkait insiden yang pernah terjadi belum terlihat realisasinya

Peran perawat anak dalam mencegah cedera diketahui bahwa pencegahan cedera yang dilakukan perawat dalam implementasi keselamatan pasien dilakukan dengan membangun komunikasi saat operan apabila ditemukan masalah pada pasien, memberikan pelayanan yang aman dari diri sendiri sebagai pemberi perawatan dan perlindungan terhadap pasien serta melakukan tindakan pelayanan berdasarkan SOP. Berdasarkan hasil observasi didapat belum tersedianya bukti solusi terhadap keselamatan pasien. Perawat di pelayanan anak melakukan pemberian solusi terkait keselamatan pasien secara lisan, misalnya saat melakukan operan diberitahu masalah yang terjadi pada pasien untuk shift perawat selanjutnya, namun belum ada dikaji dalam bentuk tulisan. Padahal berdasarkan Permenkes No 11 Tahun 2017, kejadian atau masalah yang terjadi pada pasien dapat dikaji ulang sebagai pembelajaran aktif terhadap insiden sehingga bisa memberikan solusi keselamatan pasien.

\section{KESIMPULAN}

Implementasi patient safety yang dilakukan oleh kepala SMF anak, dokter anak, dan perawat pelaksana di pelayanan anak Rumah Sakit Umum Haji Medan dalam membangun kesadaran akan nilai keselamatan pasien adalah dengan memberikan pelayanan klinis yang aman dan bertanggung jawab. Dalam memimpin dan mendukung staf adalah dengan membangun komitmen dan fokus yang kuat tentang pentingnya melakukan pelayanan medis yang aman dan memprioritaskan pasien. Dalam mengintegrasikan aktivitas pengelolaan risiko adalah dengan melakukan identifikasi yaitu membuat diagnosa dan pengobatan yang rasional dan melakukan penilaian risiko melalui simbol-simbol terkait keselamatan pasien, namun risiko yang diketahui hanya terfokus kepada risiko jatuh saja. Dalam melakukan pelaporan insiden sudah berjalan dilihat dari ketersediaan buku incident report dan sudah ada pencatatan pelaporan yang dilakukan, namun dalam pelaksanaannya ditemukan keterlambatan pelaporan dan terkadang perawat tidak melakukan pelaporan karena takut dimarahi. Dalam melakukan komunikasi terkait kerjasama tim sudah berjalan dengan menggunakan metode komunikasi efektif, begitu juga terhadap pasien sudah dilakukan edukasi, penyampaian secara terbuka kepada pasien dan keluarga. Dalam mempelajari keselamatan pasien sudah dilakukan dengan berdiskusi, belajar bersamasama, namun mengidentifikasi masalah dengan RCA (Root Cause Analysis) belum dilakukan. Dalam mencegah cedera 
melalui implementasi system keselamatan pasien dilakukan dengan memberikan pelayanan dengan aman dan benar sesuai dengan SOP, menggunakan informasi yang ada tentang masalah yang terjadi pada pasien untuk dijadikan pembelajaran sudah dilakukan secara lisan, belum ada catatan mengenai pengkajian insiden untuk menemukan solusi-solusi terkait keselamatan pasien.

\section{SARAN}

Kepala SMF anak disarankan melaksanakan pertemuan dan diskusi khusus tentang implementasi patient safety di pelayanan anak untuk mempelajari keselamatan pasien bersama-sama. Kemudian Kepala SMF anak, dokter dan perawat pelaksana di pelayanan disarankan membahas tentang pembelajaran insiden keselamatan pasien yang pernah terjadi dan isu keselamatan pasien untuk mencegah insiden yang sama terulang kembali dan meningkatkan kesadaran akan keselamatan pasien serta menunjuk penggerak keselamatan pasien di pelayanan anak sebagai orang yang bertanggung jawab menggerakkan.

\section{UCAPAN TERIMA KASIH}

Kami mengucakan terima kasih sebesarbesarnya kepada Direktur Rumah Sakit Umum Haji Medan, Kepala SMF Anak, Perawat Anak, Dokter Anak beserta seluruh staf dan karyawan serta dan semua keluarga yang telah medukung.

\section{DAFTAR PUSTAKA}

1. Schatkoski, AM., Wegner, W., Algeri, S., Pedro, E.N.R. Safety and protection for hospitalized children: Literature Review.
Revista Latino Americana deEnfermagem. 2009. Vol 7(no 3) : 4106.

2. Matlow, A. (2012). Adverse events among children in Canadian hospitals: the canadian paediatric adverse events study. Journal of CMAJ Group, 184 (13) E709- E718; DOI: https://doi.org/10.1503/cmaj.112153

3. Peraturan Menteri Kesehatan Republik Indonesia Nomor 11 Tahun 2017 Tentang Keselamatan Pasien. Permenkes RI;2017

4. Cahyono, JBS. Membangun budaya keselamatan pasien dalam praktek kedokteran. Jakarta;2008

5. Wardhani, Viera. Buku ajar manajemen keselamatan pasien. Malang. UB Press; 2017

6. Tristantia, Arfella. Evaluasi sistem pelaporan insiden keselamatan pasien di rumah sakit. 2018. Jurnal Administrasi Kesehatan Indonesia. Diakses dari https://ejournal.unair.ac.id/JAKI/article/vi ew/68 95

7. Firawati., Pabuty, A., dan Putra, A. (2012). Pelaksanaan program keselamatan pasien di RSUD Solok. Jurnal Kesehatan Masyarakat. Diakses dari

http://journal.unhas.ac.id/index.php/jkm /article/view/21353

8. Islami, K. (2018). Analisis Pelaksanaan Program Keselamatan Pasien di Puskesmas Mangkang Kota Semarang. Jurnal Kesehatan Masyarakat. 2020. Vol 8 , No 5.

9. Simamora, Roymond, H. (2018). Buku ajar keselamatan pasien melalui timbang terima Pasien Berbasis Komunikasi Efektif: SBAR. Medan. USU Press 